\title{
Options for Incorporating Energy Efficiency into Extension Programs: A Menu of Possibilities for Extension Energy Programming in Your Community ${ }^{1}$
}

\author{
Lee Hayes Byron, Alane Humrich, Marianne Schmink, Jennison Kipp, Kimberly Davis, and Paul \\ Monaghan²
}

This EDIS document is part of a series showing how Extension agents, community activists and sustainability educators can implement a program that reduces energy use and saves money on utility expenses for low-income households. This document outlines a range of options for Extension agents to consider when planning to integrate energy education into their Extension programs. It provides initial steps that require little to no resources, as well as additional possibilities at medium to higher costs (both financially and in terms of staff time). The other documents in the series include:

\section{- Developing Extension Programming to Help Low-Income} Families Save Money and Energy: The Community Weatherization Coalition Model; AEC705: Provides an in-depth case study of one successful model of a home energy tune-up/audit program in Alachua County, called the Community Weatherization Coalition.

- Community-Based Home Energy Tune-up/Audit Programs; AEC747: Outlines the steps to evaluate and develop a volunteer-based in-home energy tune-up/audit program in a community. It uses programs in Alachua and Sarasota Counties to provide examples of two different approaches to achieving the same goals.

\section{How can Extension agents add energy content to their programs?}

There are many ways to implement energy-saving programs through Extension with benefits for both residents and community organizations and businesses. Program types are listed below that represent various levels of effort and a range of availability of staff and funding. It is possible to start small, incorporating energy- and water-saving messages into existing programs with synergistic themes such as financial management, climate change, water quality, and more. Programs can then be ramped up over time, starting with education and building to more detailed technical assistance and provision of efficiency devices. No matter the scale of the program, these efficiency measures will support positive environmental, economic, and social benefits for those participating in the programs. Recognizing limitations on resources in Extension offices, the options outlined below are provided in an order that starts with the lowest level of effort required and builds to those options that require additional staff capacity and financial resources to purchase supplies and even provide grants to the community.

1. This publication is AEC748, one of a series of the Department of Agricultural Education and Communication, UF/IFAS Extension. Original publication date February 2022. Visit the EDIS website at https://edis.ifas.ufl.edu for the currently supported version of this publication.

2. Lee Hayes Byron, county Extension director and program Extension agent II, UF/IFAS Extension Sarasota County; Alane Humrich, program director, Community Weatherization Coalition; Marianne Schmink, professor emerita, Latin American studies; Jennison Kipp, Sustainable Floridians state coordinator, Program for Resource Efficient Communities; Kimberly Davis, Extension agent, Florida A\&M University Cooperative Extension; and Paul Monaghan, associate professor, Extension education, Department of Agricultural Education and Communication; UF/IFAS Extension, Gainesville, FL 32611.

The Institute of Food and Agricultural Sciences (IFAS) is an Equal Opportunity Institution authorized to provide research, educational information and other services

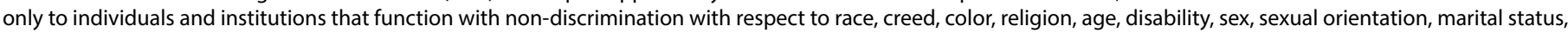

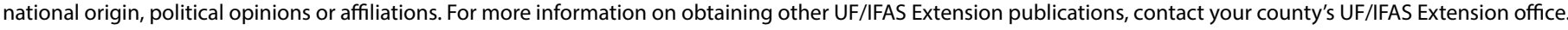
U.S. Department of Agriculture, UF/IFAS Extension Service, University of Florida, IFAS, Florida A \& M University Cooperative Extension Program, and Boards of County Commissioners Cooperating. Andra Johnson, dean for UF/IFAS Extension. 


\section{Community Outreach:}

Display information at tabling events around your community, from Resource or Housing Fairs to Earth Day Festivals, to spread the word about energy and water efficiency; recruit clients or volunteers at these events, if applicable; provide educational handouts with efficiency strategies. If funding allows, also provide giveaways, such as energy-saving light bulbs or water-saving shower heads.

\section{Efficiency Education:}

Provide household energy efficiency/utility-bill saving workshops for residents, focusing on low-income and diverse audiences. Reach these populations through neighborhood associations, affordable housing providers, faith and civic groups and libraries in low-income areas, and nonprofit partners who provide services for them. Sarasota County offers a one-hour Energy Upgrade workshop that goes through energy- and water-saving strategies and outlines incentives and resources to help pay for them.

\section{Efficiency Education with Device Distribution:}

Low-income residents may want to make efficiency improvements but cannot afford the technologies to do so. By combining the workshops above with distribution of DIY Energy and Water Saving Kits, you can help participants take the first steps to implement the strategies suggested and immediately see the benefits. Sarasota County's kits are valued at around $\$ 30$ and estimated to save households around $\$ 160$ annually when fully installed. CWC's DIY program loans out kits with materials valued at around $\$ 90$, along with necessary tools, instructional diagrams, and videos.

\section{Efficiency Resource Kits:}

Create a check-out Home Energy Efficiency Backpack or Do-It-Yourself Audit kit program, dispersed through your local library or a local nonprofit or government partner. These items can be used by residents to evaluate their home efficiency options on their own. Include in the kit/ backpack:

- A checklist and instructions on how to evaluate one's home energy/water use and major appliances.

- Evaluation tools and resources such as a ruler to measure insulation, an infrared thermometer to identify leaks, and books to learn more.
- Free supplies or devices as resources allow and the tools needed to install them.

Consider both youth-focused and adult kits/backpacks. Sarasota County, Duval County and Alachua County have these types of kits available through their libraries or the CWC.

\section{Efficiency Consultations:}

Set up help desks or phone/webinar appointments where staff or volunteers can answer questions about energy and water efficiency for interested residents. These can be done at Extension offices, over the phone or virtually, or in partnership with human service agencies where low-income residents are going to receive other services. In short interactions ( $10-15$ minutes), simple suggestions can be provided, and individual questions can be answered with follow-up later if needed. Kits or individual efficiency devices can be provided to participants in a customized way based on what they identify as savings opportunities.

\section{In-Home Energy Tune-up/Audit Programs:}

Volunteers can be trained to serve as "Energy Coaches" that serve low-income households through some of the strategies outlined above as well as more in-depth in-home audit and retrofit activities. Community-Based Home Energy Tune-up/Audit Programs provides details on how to design and implement these types of programs.

\section{Nonprofit and Business Programs:}

Nonprofits and businesses can benefit from similar types of services supporting efficiency in their operations as those outlined for residents above: tabling/outreach, educational workshops, and technical assistance. Examples of more in-depth programs for these audiences are below.

- Green Business Certification Program: Establish a checklist of sustainable operation strategies and an evaluation process for organizations to go through and then be certified as a green business. This can include steps of a waste audit and energy assessment that is usually offered to commercial customers by the local utilities. Sarasota County's Green Business Partnership has over 200 participating businesses and nonprofits.

- Energy Audits: Perform detailed energy and water audits for local nonprofits to help them identify strategies to save on their operating expenses and put more resources to their missions. Target housing groups and nonprofits working with low-income residents to ensure the benefit 
goes to those most in need. Provide a detailed report with prioritized strategies they can implement over time as funding is available and as part of their ongoing maintenance efforts. These can be conducted on a small scale for an office or small client-base with staff and a few dedicated volunteers or on a larger scale using a more robust volunteer-led program or grant funding to pay professional auditors.

- Efficiency Grants: If funding is available, it is best to pair the audits with funding to implement the suggested improvements. This can be in the form of grants to the nonprofits with or without a matching requirement and/ or the purchase and distribution of efficiency devices or appliances. Local community or family foundations that already support these nonprofits may be interested in supporting these initiatives, to help their program dollars go further by avoiding wasted operational expenditures. Sarasota County's Partners for Green Places program brought together four local funders to support such an initiative.

- Solar Grants/Financing: If further funding can be identified, the next step would be to support nonprofits in achieving net-zero energy use through the installation of solar photovoltaic on their facilities. This would involve solar assessments (which could be included in the energy audit process above) to determine feasibility and return on investment, as well as grants or financing to make the priority projects possible. Sarasota County's program is in the process of implementing a combination grant/loan program for solar on four local nonprofits.

\section{Conclusion}

No matter the extent to which your Extension office is able to implement these programs, any addition of support for community members in reducing their energy use and utility bills will have beneficial impacts in terms of economic, environmental, and social outcomes. Extension Agents can start small, evaluating overlaps in content and goals with their existing programs and stakeholder groups and build from there over time.

\section{Publications in This Series}

Developing Extension Programming to Help Low-Income Families Save Money and Energy: The Community Weatherization Model (https://edis.ifas.ufl.edu/publication/WC368)

Using Community-Based Social Marketing to Improve Energy Equity Programs
Community-Based Home Energy Tune-up/Audit Programs: A Step-by-Step Guide to Creating and Implementing Energy Equity Programs in Your Community

Options for Incorporating Energy Efficiency into Extension Programs: A Menu of Possibilities for Extension Energy Programming in Your Community 